\title{
Psychiatric Aspects of Infectious Diseases
}

\author{
Amir Mufaddel1* , Abdelaziz A. Omer², Mohamed Omar Salem \\ ${ }^{1}$ Community Mental Health Services, Behavioural Sciences Institute, Al Ain Hospital, UAE \\ ${ }^{2}$ University of Khartoum, Khartoum, Sudan \\ ${ }^{3}$ Al-Ahli Hospital, Doha, Qatar \\ Email: ${ }^{*}$ khalifaamir@yahoo.co.uk
}

Received 2 May 2014; revised 1 June 2014; accepted 24 June 2014

Copyright (C) 2014 by authors and Scientific Research Publishing Inc.

This work is licensed under the Creative Commons Attribution International License (CC BY). http://creativecommons.org/licenses/by/4.0/

\section{Abstract}

Psychiatric symptoms can be associated with several systemic and central nervous system infections and they can be the initial presenting symptoms, occurring in the absence of neurological symptoms in some disorders as in some cases of viral encephalitis. They could also be part of the clinical picture in other cases such as psychosis or mood symptoms secondary to brucellosis or toxoplasmosis. Late-onset neuropsychiatric complications may also occur several years following the infection such as in the case of subacute sclerosing panencephalitis due to measles. Some Infectious diseases may have possible etiological role for major psychiatric disorders, based on yet unconfirmed reports for viral infectious diseases (e.g. Influenza virus and HSV-1) which are thought to have risk for developing schizophrenia and psychosis. Neuropsychiatric adverse effects can occur due to drugs (e.g. mefloquine, interferon-alpha) that are used for treatment of infectious diseases. Psychiatric symptoms can also be reactivated resulting from chronic, complicated and serious infections such as HIV that can lead to depression, anxiety or adjustment disorders, although CNS involvement can also be a possible etiological factor. Patients suffering from primary and severe psychiatric disorders are at increased risk of contracting infection; that is mainly related to high risk behaviors in patients with mania or schizophrenia. It is also important to consider that the co-occurrence of psychiatric symptoms and infection can be incidental (i.e. infectious diseases can occur in psychiatric patients regardless of the above mentioned factors). Early identification of the underlying etiology for organic/secondary psychiatric symptoms is essential for appropriate intervention and early treatment of the primary condition that could be the etiology of psychiatric symptoms so as to avoid unnecessary long-term psychiatric treatment and to avoid complications of possible misdiagnosis or delayed diagnosis of the primary condition.

\section{Keywords}

Bacterial Infections, Viral Infections, Parasitic Infections, Psychiatric Symptoms, Neuropsychiatric Features

\footnotetext{
"Corresponding author.
} 


\section{Introduction}

Infectious organisms can play an important role in pathophysiology of neurodegenerative and neurobehavioral diseases. They may enter the brain within infected migratory macrophages, or they may cross the blood-brainbarrier by the process of transcytosis or by intraneuronal transfer from peripheral nerves [1]. Psychiatric symptoms can occur as part of the clinical manifestations of several systemic and central nervous system infections. On the other hand, psychological stress can affect the function of the immune system and predict infectious diseases susceptibility [2]. In psychiatric settings, people with severe mental illness have more susceptibility to develop physical illness than general population [3]. Studies investigating infectious diseases in psychiatric population revealed high rates of infectious diseases. For example, screening of 588 adult psychiatric patients in 2 psychiatric inpatient units in University of Pennsylvania, has shown that evidence of undetected diseases was reported in about $10 \%$ of patients who had HIV, 32\% who had hepatitis B, and $21 \%$ who had hepatitis C, and a considerable proportion of infectious diseases have been missed [4]. Occasionally, even a small focus of chronic infection can result in organic psychiatric disorder with symptoms of subtle cognitive dysfunction, irritability, depression, psychosis and delirium. Occult infections are concealed infections that may occur anywhere in the body, and can be associated with various psychiatric symptoms. Examples include: urinary tract infections, abscess, sinusitis, chronic otitis, bronchiectasis, cholecystitis, parasitosis, osteomyelitis, endocarditis, sinusitis and subclinical systemic infections (such as tuberculosis and HIV) [5]-[7]. A wide range of psychiatric symptoms can occur in febrile illnesses. Study of febrile onset psychiatric symptoms in Sudan has shown that at least a third of the patients had psychiatric symptoms including excitement, aggressive behavior, sleep disturbance, visual hallucinations, auditory hallucinations, delusions, disorganized thinking and disorientation. Other reported symptoms were depression, mutism, and catatonia [8].

Also, maternal and childhood infections are considered as risk factors for psychosis. The fetal brain can be exposed to maternally derived substances, such as cytokines or stress hormones. Several studies have found association between the later developments of psychosis and exposure to infections during fetal life. Exposures to viruses with affinity to the CNS, (e.g. Influenza A virus, polio, rubella, and herpes simplex Type 2 viruses), have been proposed as risk factors for developing psychosis in addition to the parasite T. gondii [9] [10]. Case control studies including patients with schizophrenia and other psychotic illness found significantly elevated levels of total and IgM immunoglobulins in affected individuals. A significant association was found between maternal antibodies to herpes simplex virus Type 2 glycoprotein gG2 and subsequent psychotic illness [11]. A large birth cohort, including subjects born from 1959 through 1966, found a 7-fold increased risk of schizophrenia for influenza exposure during the first trimester; while Influenza exposure in early-to-mid-pregnancy was associated with 3-fold increased risk of schizophrenia [12]. A national cohort study consisting of 1.2 million children followed up by using Swedish national registers to retrieve data on hospital admissions for CNS infections at 0 - 12 years of age, found a slightly increased risk of non-affective psychosis associated with viral CNS infections, as well as schizophrenia. They found no evidence of increased risk in relation to bacterial infections. Exposures to mumps virus or cytomegalovirus were associated with subsequent psychoses. The association with specific viruses indicates that the risk is related to infectious agents with a propensity to invade the brain parenchyma [13]. On the other hand, some studies found no association between common childhood infectious diseases and developing psychiatric illness. For example, using data from the UK National Child Development Study, a longitudinal general population sample was investigated for possible associations of adult-onset psychosis with neurological soft signs and common childhood infectious illnesses. Schizophrenia, affective psychosis and epilepsy were not associated with common childhood illness but were associated with neurological soft signs and an increased, but small, frequency of previous meningitis and tuberculosis [14].

Maternal bacterial infections are also thought to be associated with risk of developing psychosis. A study using Copenhagen Perinatal Cohort data has identified 85 cases of schizophrenia. In these cases, first-trimester exposure to bacterial infections was associated with an elevated risk of developing schizophrenia, suggesting a relationship between maternal bacterial infection during pregnancy and offspring risk of schizophrenia; most likely respiratory tract and gonococcal infections [15].

Association between risk of schizophrenia and prenatal exposure to infections (both viral and bacterial) may be mediated through trans-placental passage of cytokines produced by the mother in response to infections. For example, Interleukin-8 (IL-8) crosses the placenta barrier and has been implicated in early brain development [16]. Increased risk of schizophrenia was also thought to be associated with coxsackie B5 during neonatal period 


\section{[17] [18].}

If the psychiatric symptoms are secondary to infectious disease process, the diagnosis is most likely to be organic psychiatric disorder or psychiatric disorder due to a medical condition, rather than primary/functional psychiatric illness. In addition to infections, there are several physical causes that contribute to the etiology of organic psychiatric disorders such as drugs, neurological conditions, constipation, dehydration, pain and vascular causes. Febrile illness (e.g. urinary tract infection), septicemia and encephalitis can lead to delirium. Dementia can be caused by infections such as HIV, neurosyphilis, post encephalitis syndromes and Lyme disease [5] [6]. Other organic mental disorders classified in ICD-10 include organic hallucinosis, organic catatonic disorder, organic delusional or schizophrenia-like disorder, organic mood disorder, organic anxiety disorder and organic personality disorder.

It is of vital importance to differentiate psychiatric symptoms resulting from organic causes from those coincidentally occurring in a patient suffering from a primary psychiatric disorder.

This review will focus on the relation between infectious diseases and psychiatric symptoms with emphasis on the psychiatric manifestations of various infectious diseases including viral, bacterial and parasitic infectious diseases.

Generally, the relation between infectious diseases and psychiatric features can be summarized as follows (Table 1):

a) Infectious diseases causing psychiatric symptoms: In these cases, psychiatric symptoms can be the initial presenting symptoms, (as in viral encephalitis), or could be part of the clinical picture in others (such as psychosis or mood symptoms in brucellosis or toxoplasmosis).

b) Infectious diseases with possible etiological role for major psychiatric disorders: There are unconfirmed reports for infectious diseases (e.g. Influenza virus and HSV) with possible etiological role for schizophrenia. [10] [11].

c) Psychiatric symptoms due to adverse effects of drugs used for treatment of the infectious disease: e.g. mefloquine, INF.

d) The primary psychiatric disorders can increase the risk of contracting infection: High risk behaviors in patients with mania and schizophrenia may lead to increased risk of infection.

e) Psychiatric symptoms reactive to chronic and serious infections: e.g. chronic, complicated and serious infections such as HIV can lead to depression, anxiety or adjustment reactions.

f) Others/coincidental: e.g. infectious diseases can occur in psychiatric patients regardless of the above mentioned factors.

In this review, such relations will be discussed under the possible causing agents.

Work-up and differential diagnosis of co-existing psychiatric symptoms and infectious diseases are shown in Figure 1.

\section{Bacterial Infections}

Bacteria are unicellular organisms traditionally classified, according to the Gram stain, into Gram-positive and Gram-negative organisms. Using light microscopy, they can be divided into cocci and bacilli (rods). Many in-

Table 1. Relation between infectious diseases and psychiatric features.

\begin{tabular}{|c|c|c|}
\hline Pattern of relation & Comment & Examples \\
\hline $\begin{array}{l}\text { Infectious diseases causing psychiatric } \\
\text { symptoms }\end{array}$ & $\begin{array}{l}\text { Psychiatric symptoms can be the initial presenting } \\
\text { symptoms, or could be part of the clinical picture of } \\
\text { the infectious disease. }\end{array}$ & $\begin{array}{l}\text { - } \quad \text { Viral encephalitis. } \\
\text { - Psychosis or mood symptoms in } \\
\text { brucellosis or toxoplasmosis. }\end{array}$ \\
\hline $\begin{array}{l}\text { Infectious diseases with possible etiologica } \\
\text { role for major psychiatric disorders }\end{array}$ & $\begin{array}{l}\text { I Unconfirmed reports for infectious diseases having } \\
\text { possible etiological role for schizophrenia. }\end{array}$ & $\begin{array}{l}\text { - Influenza virus. } \\
\text { - HSV. }\end{array}$ \\
\hline $\begin{array}{l}\text { The primary psychiatric disorders can } \\
\text { increase the risk of contracting infection }\end{array}$ & $\begin{array}{l}\text { High risk behaviors may lead to increased risk of } \\
\text { infection. }\end{array}$ & $\begin{array}{l}\text { - Acute and severe psychiatric } \\
\text { symptoms (e.g. Mania). } \\
\text { - Chronic psychiatric symptoms (e.g. } \\
\text { schizophrenia) }\end{array}$ \\
\hline $\begin{array}{l}\text { Psychiatric symptoms reactive to chronic } \\
\text { and serious infections }\end{array}$ & $\begin{array}{l}\text { Chronic, complicated and serious infections can lead } \\
\text { to depression, anxiety or adjustment reactions. }\end{array}$ & - HIV. \\
\hline Others/coincidental & $\begin{array}{l}\text { Infectious diseases can occur in psychiatric patients } \\
\text { regardless of the above mentioned factors. }\end{array}$ & \\
\hline
\end{tabular}




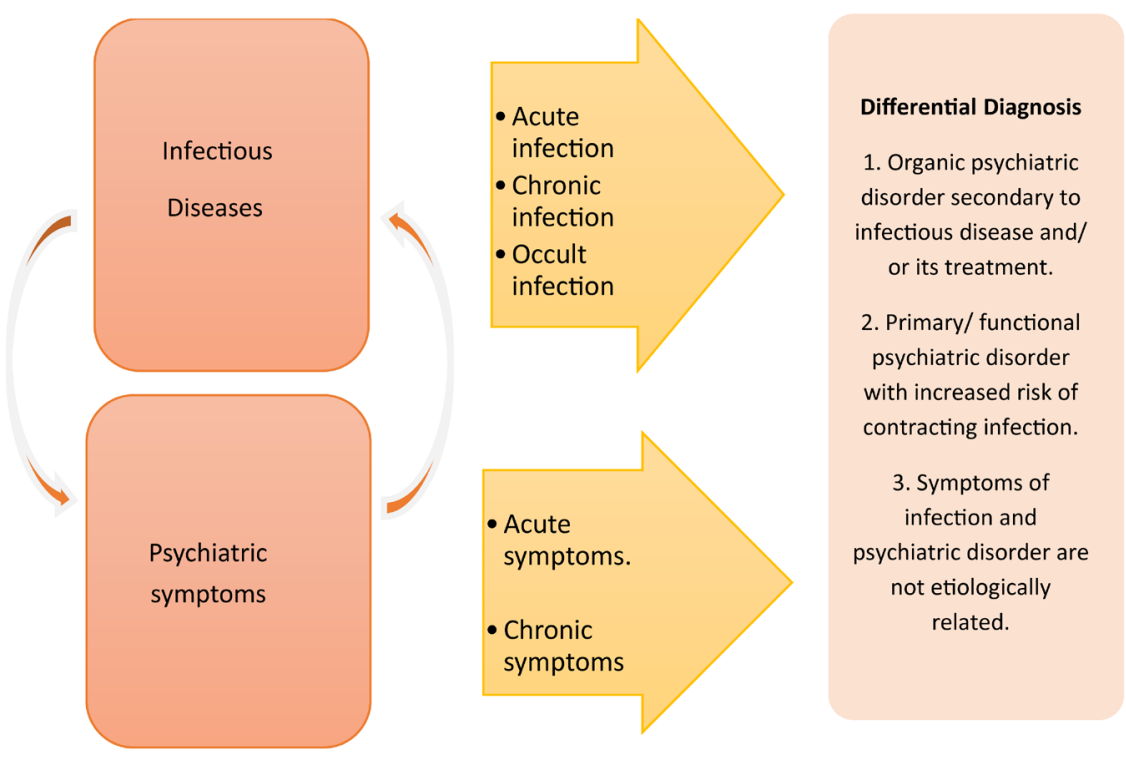

\begin{abstract}
Figure 1. Differential diagnosis of co-existing psychiatric symptoms and infectious diseases. Infectious diseases can cause acute or chronic psychiatric symptoms. On the other hand, patients with psychiatric symptoms can be at increased risk of contracting infection due to high risk behaviors such as that associated with acute relapses (e.g. mania) or chronic negative or positive symptoms of schizophrenia. If acute or chronic infections are suspected in a patient with psychiatric symptoms, then assessment for both conditions should go parallel to identify the pattern of symptoms and possible etiology. Differential diagnosis, based on such assessment, should include possibility of organic psychiatric disorder or primary/functional psychiatric disorder. However, symptoms of infection and psychiatric disorder could also be not etiologically related.
\end{abstract}

fections are confined to a particular body organ or system, while other infections can potentially affect several systems or the entire body and, under unusual circumstance, they may become systemic. Bacteraemia (transient presence of organisms) and septicemia (illness arising from blood-borne infections) may occur. Meningococcal septicemia causes typical features of septic shock such as fever, myalgia and hypotension [16]. Cell wall-deficient bacteria (e.g. Mycoplasma, Chlamydia, Borrelia and Brucella) may play important roles in neurodegenerative and neurobehavioral diseases [1]. Examples of Neuropsychiatric symptoms that can be associated with bacterial infections are summarized in Table 2.

\title{
2.1. Pediatric Autoimmune Neuropsychiatric Disorders Associated with Streptococcal Infections (PANDAS)
}

PANDAS are a group of childhood-onset neuropsychiatric disorders which have a post-infectious autoimmune-mediated etiology, and they are found to be related to infections with group-A beta-hemolytic streptococci (GABHS) [19]. The course is typically episodic with varying symptoms severity and there is a common association with neurologic signs [20]. Children with PANDAS have unique clinical characteristics including [19] [21] [22]:

- Presence of obsessive compulsive disorder (OCD) and tics.

- Very young age-at-onset (pre-pubertal).

- Abrupt onset or episodic course of symptom severity.

- Symptom exacerbations are sudden and dramatic and are associated with GABHS infections.

- Exacerbations associated with motor abnormalities (such as chorieform movements) distractibility and impulsivity.

- Invariable response to antibiotics, and immune modulating regimens.

- There is an increased rate of separation anxiety, impulsivity, hyperactivity, enuresis and deterioration in handwriting in children with PANDAS.

One case-control study investigated children aged 4 to 13 years who received their first diagnosis of OCD, 
Table 2. Examples for bacterial infections that can be associated with neuropsychiatric symptoms.

\begin{tabular}{|c|c|c|c|c|}
\hline $\begin{array}{l}\text { Bacterial } \\
\text { infection }\end{array}$ & $\begin{array}{l}\text { Causative } \\
\text { organism }\end{array}$ & Clinical features & Neuropsychiatric symptoms & Diagnosis \\
\hline Brucellosis & $\begin{array}{l}\text { Gram-negative } \\
\text { coccobacilli: } \\
\text { B. abortus, } \\
\text { B. mellitensis, } \\
\text { B. suis, B. canis. }\end{array}$ & $\begin{array}{l}\text { The incubation period for acute } \\
\text { infection is } 1 \text { - } 3 \text { weeks. Malaise, } \\
\text { headache, weakness, generalized } \\
\text { myalgia and night sweat. The fever } \\
\text { pattern is undulant. } \\
\text { Lymphadenopathy, } \\
\text { hepatosplenomegaly, spinal } \\
\text { tenderness, scaroiliitis. }\end{array}$ & $\begin{array}{l}\text { Behavioral changes, chronic } \\
\text { psychosis, stupor, hallucination, } \\
\text { delirium, and acute psychosis can be } \\
\text { an early presentation of brucellosis. } \\
\text { Depression is common in untreated } \\
\text { chronic forms of brucellosis. }\end{array}$ & $\begin{array}{l}\text { Blood or bone marrow } \\
\text { cultures in acute phase. } \\
\text { Serological tests for } \\
\text { chronic brucellosis } \\
\text { (brucella agglutination } \\
\text { test). Polymerase chain } \\
\text { reaction. ELISA. }\end{array}$ \\
\hline Typhoid fever & Salmonella typhi & Abdominal pain, headache, fever & $\begin{array}{l}\text { Common: delirium, encephalopathy. } \\
\text { Less commonly: Persistent } \\
\text { psychiatric symptoms (irritability, } \\
\text { psychosis, and personality changes), } \\
\text { complete recovery following } \\
\text { treatment. }\end{array}$ & $\begin{array}{l}\text { Blood culture }\left(1^{\text {st }} 2\right. \\
\text { weeks), Intestinal } \\
\text { secretions and urine } \\
\text { culture, Bone marrow } \\
\text { culture is rarely required, } \\
\text { leucopenia, Widal } \\
\text { antigen test can be } \\
\text { misinterpreted. }\end{array}$ \\
\hline Syphilis & $\begin{array}{l}\text { Treponema pallidum } \\
\quad \text { (T. Pallidum) }\end{array}$ & $\begin{array}{l}\text { Primary stage: hard chancre, } \\
\text { regional lymphadenopathy. } \\
\text { Secondary stage: fever, malaise, } \\
\text { arthralgia, sore throat, generalized } \\
\text { lymphadenpathy. maculopapular } \\
\text { rash, mucous patches, snail-track } \\
\text { ulcers. } \\
\text { Tertiary (late) stage: Gummas, } \\
\text { aortitis, neurosyphilis. }\end{array}$ & $\begin{array}{l}\text { Neurosyphilis: General Paralysis of } \\
\text { Insane, symptoms similar to } \\
\text { Alzheimer disease, progressive } \\
\text { cognitive decline, seizures, } \\
\text { personality change, encephalopathy. }\end{array}$ & $\begin{array}{c}\text { Dark ground microscopy, } \\
\text { serological, CSF } \\
\text { examination for evidence } \\
\text { of neurosyphilis, Chest } \\
\text { X-ray. }\end{array}$ \\
\hline Lyme disease & Borrelia burgdorferi & $\begin{array}{l}\text { The first stage ( } 7 \text { - } 10 \text { days): } \\
\text { Erythema migrans at the site of tick } \\
\text { bite, headache, fever, malaise, } \\
\text { myalgia, arthralgia, } \\
\text { lymphadenopathy. } \\
\text { The second stage: neurological } \\
\text { symptoms, cardiac symptoms, } \\
\text { arthritis. }\end{array}$ & $\begin{array}{l}\text { Decreased memory, poor } \\
\text { concentration, difficulties in } \\
\text { formulating ideas and difficulty in } \\
\text { word findings, irritability, daytime } \\
\text { hypersomnolence, depression. }\end{array}$ & $\begin{array}{l}\text { IgM antibodies are } \\
\text { detectable in the first } \\
\text { month. IgG antibodies } \\
\text { invariably present later. }\end{array}$ \\
\hline Leptospirosis & Leptospira Interrogans & $\begin{array}{c}\text { Leptospiraemic phase: severe } \\
\text { headache, malaise, fever, anorexia, } \\
\text { myalgia, conjunctival suffusion, } \\
\text { hepatosplenomegaly, } \\
\text { lymphadenopathy, skin rash. } \\
\text { Immunological phase:usually mild. } \\
\text { Meningism. }\end{array}$ & $\begin{array}{l}\text { Commonly: Confusion and } \\
\text { delirium. } \\
\text { Mania and psychosis may } \\
\text { occur. }\end{array}$ & $\begin{array}{l}\text { Usually clinical only. } \\
\text { Blood/CSF culture, } \\
\text { leucocytosis, } \\
\text { thrombocytopenia, } \\
\text { elevated creatine } \\
\text { phosphokinase. }\end{array}$ \\
\hline $\begin{array}{c}\text { Mycoplasma } \\
\text { pneumonia }\end{array}$ & $\begin{array}{l}\text { Mycoplasma } \\
\text { pneumoniae }\end{array}$ & $\begin{array}{l}\text { Headache and malaise preceding the } \\
\text { chest symptoms. } \\
\text { Extrapulmonary: myocarditis, } \\
\text { pericarditis, erythema multiforme, } \\
\text { arthralgia, gastrointestinal } \\
\text { symptoms, haemolyticanaemia, } \\
\text { thrombocytopenia, } \\
\text { meningoencephalitis. }\end{array}$ & $\begin{array}{l}\text { Encephalitis, meningitis, myelitis, and } \\
\text { polyradiculitis. Other reported pres- } \\
\text { entations include coma, ataxia, psy- } \\
\text { chosis, and stroke. Rarely: } \\
\text { Kluver-Bucy syndrome }\end{array}$ & $\begin{array}{l}\text { Chest X-ray, cold } \\
\text { agglutinins, rising } \\
\text { antibody titre, }\end{array}$ \\
\hline $\begin{array}{l}\text { Whipple's } \\
\text { Disease }\end{array}$ & Tropheryma whipplei & Arthralgia, diarrhea, weight loss. & $\begin{array}{l}\text { Commonly: Depression and } \\
\text { personality changes. } \\
\text { More common: cognitive } \\
\text { dysfunction and dementia. }\end{array}$ & \\
\hline
\end{tabular}

Tourette's syndrome (TS), or tic disorder. They found that streptococcal infection doubles the risk for a first diagnosis of OCD, TS, or tic disorder within the 3 months following the infection, and multiple infections seemed to approximately triple the risk for a first diagnosis within 12 months' time [21]. Other factors may include psychosocial stress which can be associated with future worsening of tic, OC and depressive symptoms [23] [24].

A rapid rise in anti-streptococcal (ASO) titer is the best way that can show the association between recent GABHS infection and symptoms onset and exacerbations of PANDAS. A throat culture should also be obtained although some children with PANDAS may not have sore throat [7]. Penicillin prophylaxis has known effectiveness for rheumatic fever in which group A beta-hemolytic streptococcus played etiological role. The role of antibiotic prophylaxis for childhood-onset neuropsychiatric disorders was investigated in a double blind rando- 
mized controlled trial which found penicillin and azithromycin to be effective in decreasing streptococcal infections and reducing exacerbations of neuropsychiatric symptoms among children with PANDAS [25].

\subsection{Mycoplasma Pneumonia}

Mycoplasma refers to a genus of bacteria that lack a cell wall. Mycoplasma pneumonia accounts for $2.4 \%$ - 14\% of community acquired pneumonia and most of the patients develop mild upper respiratory tract infection. Clinically apparent pneumonia occurs in 3\% - 10\% of cases [26]. Mycoplasma pneumoniae, the smallest free living bacteria, has minor ability to injure respiratory cells and is known to cause various extra-pulmonary manifestations that almost affect all organs. The neurological manifestations are the most frequently reported presentations [27]. CNS manifestations occur in one of 1000 patients with infections including encephalitis (the most frequent), meningitis, myelitis, and polyradiculitis. Other reported presentations include coma, ataxia, psychosis, and stroke. There are also some reported cases of psychosis following resolution of mycoplasma pneumonia [28]-[31]. New manifestations have been described following Mycoplasma pneumoniae infection such as KluverBucy syndrome $\&$ intracranial hypertension which need to be confirmed. Kluver-Bucy syndrome is a rare neurobehavioral condition first described on the basis of experimental bilateral temporal lobectomy in monkeys. The syndrome is characterized by visual agnosia, excessive oral tendencies (putting objects into mouth, licking, biting, chewing, touching with lips, and bulimia), hypermetamorphosis, placidity, altered sexual behavior, and changes in dietary habits. In a reported case of kulver-Bucy syndrome associated with mycoplasma pneumonia, MRI revealed left temporal horn dilation and asymmetry of both temporal lobes. The pathophysiology was suggested to be immune-mediated damage by $M$. pneumoniae resulting in vasculopathy. The common etiologies of Kulver-Bucy Syndrome reported in humans include herpes simplex encephalitis, toxoplasmosis, tuberculous meningitis, head trauma, hypoxia, hypoglycemia, heat stroke, Parkinson's disease, Alzheimer's disease and Huntington's disease [31]-[33].

\subsection{Lyme Disease}

Lyme borreliosis is a tick-borne multisystem inflammatory disease caused by the spirochete Borrelia burgdorferi sensu stricto, in the United States and Borrelia garinii and Borrelia afzelii in Europe. Spirochaetes are double-membrane bacteria, most of which have long, helically coiled (spiral-shaped) cells. Lyme disease can be of relapsing and remitting nature and can be refractory to normal immune surveillance and standard antibiotic regimens. The disease, as with other spirochetal infections like syphilis, occurs in acute and chronic stages with a wide spectrum of clinical picture. The most common early manifestation is a skin lesion at the site of the tick bite. The hall mark of the disease is the characteristic erythema migrans, rash manifests as an area of spreading erythema measuring $>5 \mathrm{~cm}$ in diameter. Later manifestations are caused by spread of the spirochetes either under the skin or via blood stream to the brain, heart and joints. Neurologic manifestations (Lyme Neuroborreliosis) occur after several weeks to months in $15 \%$ of patients [34]-[36].

A broad range of psychiatric conditions have been reported in association with Lyme disease including paranoia, dementia, schizophrenia, bipolar disorder, panic attacks, major depression, anorexia nervosa and obsessive compulsive disorder [37]. Depression is common among patients with late Lyme disease occurring in $26 \%$ to $66 \%$ of cases. Lyme disease should be included in the differential diagnosis of psychiatric symptoms in patients who live in its endemic areas, particularly when presenting with certain psychiatric symptoms such as depressive features, lack of concentration and fatigue [35] [37].

Common chronic symptoms due to Lyme disease may include [36]:

- Cognitive deficits and subjective cognitive slowing: decreased memory, poor concentration, difficulties in formulating ideas and difficulty in word findings are significantly prominent in chronic post-treatment Lyme disease.

- Long-standing fatigue.

- Chronic musculoskeletal pain.

\subsection{Brucellosis}

Brucellosis is a zoonotic disease caused by gram-negative coccobacilli of four species recognized as human pathogens associated with different natural host animals including B. abortus (cattle), B. mellitensis (goats \& 
sheep), B. suis (swine) and B. canis (dogs). The clinical features range from asymptomatic seroconversion or mild flu-like illness to complicated chronic disease. The ratio of subclinical disease to symptomatic disease has been estimated to range from 1:1 to 12:1 [38].

Central nervous system manifestations occur in $5 \%-10 \%$ of cases and they could be the only presenting features. Neurological complications of brucellosis may be divided into 2 major groups: toxic-febrile neurobrucellosis (related to the acute-febrile state), and classical neurobrucellosis (related to actual invasion and localization of the pathogen in the CNS). There are reported cases of brucellosis associated with variable psychiatric presentations including behavioral changes, chronic psychosis, stupor, hallucination, delirium, and acute psychosis which could be an early presentation of brucellosis [39] [40].

Chronic brucellosis may not be preceded by acute symptoms and commonly present with fatigue, subtle cognitive deficits, depression and multiple chronic pains. Due to its presentation, chronic brucellosis is frequently misdiagnosed as primary psychiatric illness [7]. Patients with brucellosis (with or without neurological manifestations) have highly significant impairment in cognitive function parameters (such as mental control, logical memory, visual reproduction) and higher depressive symptoms compared with Controls [41].

One study using Rorschach test, (which was administered to 3 groups of patients with: neurosis, organic brain damage, and brucellosis), have shown that the brucellosis group have similarities to the neurosis group and they were also similar to the brain-damaged group in reduction of emotional spontaneity and capacity for emotional responsiveness [42].

\section{Protozoal Infections}

Protozoa are unicellular eukaryotic organisms which are more complex than bacteria. To be transmitted to a new host, some protozoa transform into hardly cyst forms and others are transmitted by an arthropod vector [18]. Certain parasites are capable of selectively altering host behaviour to enhance their transmission. Some cases of schizophrenia may be associated with environmental factors including exposure to the ubiquitous protozoan Toxoplasma gondii [43].

\subsection{Toxoplasmosis}

Toxoplasmosis is a common protozoal infection caused by the intracellular protozoan parasite Toxoplasma gondii. Seroprevalence in adults in UK is about 25\% rising up to 90\% in some parts of Europe. Most infections are asymptomatic. Symptomatic patients usually develop lymphadenopathy. Clinical features may include fever, myalgia and general malaise. In severe cases pneumonia, myocarditis and choroidoretinitis may occur [18]. Primary toxoplasmosis infection during pregnancy may cause severe damage to the foetus, and may cause microcephaly, hydrocephalus, encephalitis, mental retardation, seizures, blindness, and death. Acute T. gondii infection can cause psychotic symptoms similar to symptoms of schizophrenia [18] [44].

Many studies found significant $T$. gondii antibodies in persons with schizophrenia and other severe psychiatric disorders and the difference was statistically significant in some case-control studies [45]. Psychiatric complications due to acute $T$. gondii infection or secondary reactivation of the disease in immunosuppressed individuals include: disorientation, anxiety, depression, and schizophreniform psychoses [46]. Hydrocephalus, increased ventricular size, and cognitive impairment have also been reported in schizophrenia and other forms of psychosis [45].

The T. gondii genome contains 2 aromatic amino acid hydroxylases that potentially could directly affect dopamine and/or serotonin biosynthesis. In chronic toxoplasmosis, $T$. gondii forms cysts that can be located in various anatomical sites including the brain. Stimulation of the immune response has also been associated with mood and behavioral alterations in humans [47].

Several sero-prevalence case control studies have demonstrated significantly higher sero-prevalence and $T$. gondii IgG antibodies in patients with schizophrenia than in control subjects. T. gondii seropositivity was particularly higher in patients suffering from simple schizophrenia [48]. Analysis of serum samples for the presence and level of immunoglobulin G (IgG) to T. gondii, CMV, HSV-1, and HSV-2 in an Ethiopian population; found the seroprevalence of $T$. gondii infection and IgG to CMV higher in individuals with schizophrenia and bipolar disorder than in unaffected controls [49]. T. gondii IgG antibodies were detected in about $18.2 \%$ of psychiatric inpatients and $8.9 \%$ of controls indicating significant elevation of immunoglobulins against $T$. gondii in psy- 
chiatric population. About $26.3 \%$ of patients with schizophrenia had evidence for latent infection which was significantly higher than controls [43].

Recently, the ability of $T$. gondii to manipulate the behaviour of infected mice and rats and alter personality attributes of humans has been reported [47]. T. gondii can alter the Lister-hooded laboratory rats' perception of predation risk turning their innate aversion into a suicidal feline attraction. Among untreated rats, those infected spent "proportionately" much more time in the cat area than uninfected rats. Anti-psychotic drugs (haloperidol) were as efficient as anti-T. gondii (pyremethamine and dapson) drugs in preventing such behavioural alterations [50]. Studies investigating the neurological basis of anxiety, have demonstrated that blocking N-methyl-D-asparticacid receptors in the amygdala, and/or provision of serotonin (5-HT) antagonists, causes rats to approach cat odors fearlessly. T. gondii may change the behavior of rodents so as to make them more likely to be predated on by cats, the parasite's definitive host [51]-[53].

\subsection{Malaria}

Malaria is transmitted by female Anopheles, and it is one of the most important parasitic diseases worldwide. Five species can cause malaria in humans. These are Plasmodium falciparum, Plasmodium vivax, Plasmodium ovale, Plasmodium malariae and, recently discovered, Plasmodium knowlesi [54]. Malarial infection can be associated with a wide range of neuropsychiatric symptoms. Occasionally frankly psychotic behaviour can be the first manifestation of cerebral involvement during malarial infection. Paranoid psychosis, mania, hallucinations, and delusions were the commonest neuropsychiatric complications in some cases. Other reported presentations include: hemiplegia, cerebral palsy, rare cases of Gullain-Barre syndrome (GBS), cerebellar ataxia, extra-pyramidal symptoms, trismus, peripheral neuropathy, isolated $6^{\text {th }}$ nerve palsy, and foot drop have been reported, Ocular bobbing, nystagmus, and sudden blindness due to vitreous haemorrhage. Subarachnoid haemorrhage due to Disseminated intravascular coagulation (DIC) and myelitedes-resembling amyotrophic lateral sclerosis (ALS) and tabesdorsalis-like syndrome, and combined disseminated encephalomyelitis have also been reported [55] [56].

Neuropsychiatric impairments due to cerebral malaria in children include: long-term cognitive impairment, acquired language disorder, inattention, impulsiveness and hyperactivity, conduct disorders, impaired social development, and obsessive symptoms. Self-injurious and destructive behaviors have also been observed [9].

\subsection{Post-Malaria Neurological Syndrome (PMNS)}

This syndrome occurs after symptomatic malarial infection \& clearance of parasites from blood. It is characterized by development of neurological and psychiatric symptoms that can occur 1 - 4 months after exposure. Clinical manifestations include generalized convulsion, delayed cerebellar ataxia, psychosis, and tremors [56] [57]. The syndrome usually occurs in patients originally treated for severe malaria and is strongly correlated with mefloquine treatment [58].

\subsection{Adverse Neuropsychiatric Effects Due to Antimalarial Agents}

Agents used for prophylaxis and treatment of malaria may result in neuropsychiatric adverse effects. The quinoline antimalarial drugs (chloroquine, quinine, mefloquine) are all known for their neuropsychiatric adverse effects while artemisinin or antifolates, are not known to be associated with neuropsychiatric complications [58]. Mefloquine is an effective first line agent for preventing chloroquine-resistant malaria. Neuropsychiatric adverse effects of mefloquine include anxiety, paranoia, depression, hallucinations, psychotic behaviour and possibly suicide. Because of its adverse psychiatric symptoms, it has been recommended to avoid mefloquine in patients with history of psychiatric symptoms or seizure and to alternatively use doxycycline for prophylaxis [59]. The first case of toxic encephalopathy was published in 1987, and in 1989 the WHO initiated reporting and investigation of neuropsychiatric adverse effects of mefloquine [60]. Mefloquine-induced psychosis can be preceded by a prodromal phase of moderate symptoms such as dizziness, insomnia, and generalized anxiety followed by frank psychosis with psychomotor agitation and paranoid delusions [61]. About 28\% of patients with $P$. falciparum malaria who were treated with mefloquine developed neuropsychiatric adverse reactions [60].

Chloroquine treatment can rarely be associated with neuropsychiatric symptoms such as increased psychomotor activity, disorientation, incoherent speech, confusion \& outbursts of abnormal behavior [62]. Chloroquine 
treatment following an experimental malarial infection caused serious psychiatric symptoms in a volunteered participant including symptoms of depersonalization, anxiety, vivid unpleasant dreams, headache, photophobia and paranoid delusions which subsided over 4 months [58].

\section{Viral Infections}

Viruses enter the CNS through several mechanisms. They may replicate outside the CNS and then invade by heamatogenous spread (e.g. enteroviruses). Viral particles pass directly across the blood-brain barrier, or through infected leukocytes (e.g. mumps, measles or herpes viruses), and then infect vascular endothelial cells. Other viruses invade through peripheral (e.g. polio) and cranial nerves (e.g. herpes simplex virus). Viruses may spread through the subarachnoid space leading to meningitis. They may also spread directly or via inflammatory leukocytes through neural tissue to neurons and glial cells [63]. Most viruses that cause encephalitis can also cause meningitis. Psychiatric symptoms are very common in acute phase of viral encephalitis and they are also common after recovery [7].

Occasionally, psychiatric symptoms without neurological symptoms can be the initial presentation of viral encephalitis. Psychiatric symptoms may occur as psychosis (35\%), catatonia (33\%), psychotic depression (16\%), or mania (11\%) [64]. Examples of Neuropsychiatric symptoms that can be associated with viral infections are summarized in Table 3.

\section{Table 3. Neuropsychiatric manifestations of some viral infections.}

\begin{tabular}{|c|c|c|c|c|}
\hline Viral infection & $\begin{array}{l}\text { Causative } \\
\text { organism }\end{array}$ & Clinical features & $\begin{array}{l}\text { Neuropsychiatric } \\
\text { manifestations }\end{array}$ & Diagnosis \\
\hline $\begin{array}{l}\text { Herpes simplex } \\
\text { virus (HSV) } \\
\text { infection }\end{array}$ & $\begin{array}{l}\mathrm{HSV}-1 \\
\mathrm{HSV}-2\end{array}$ & $\begin{array}{l}\text { Herpetic stomatitis, herpes } \\
\text { labialis, keratoconjunctivitis and } \\
\text { encephalitis. } \\
\text { Genital herpes, systemic } \\
\text { infections in } \\
\text { immunocompromised host. }\end{array}$ & $\begin{array}{l}\text { Hypomania, personality changes, } \\
\text { dysarthria, seizures, autonomic } \\
\text { dysfunction, ataxia, delirium, and } \\
\text { psychosis. Rarely; Kulver-Bucy } \\
\text { syndrome }\end{array}$ & $\begin{array}{l}\text { Detection of HSV DNA by } \\
\text { polymerase chain reaction. }\end{array}$ \\
\hline $\begin{array}{l}\text { Epstein-Barr } \\
\text { Virus infection }\end{array}$ & $\begin{array}{c}\text { EBV } \\
\text { (one of the } \\
\text { herpes viruses) }\end{array}$ & $\begin{array}{l}\text { Acute febrile illness known as } \\
\text { infectious mononucleosis } \\
\text { (glandular fever), headache, } \\
\text { malaise, sore throat, cervical } \\
\text { lymphadenopathy, slenomegaly, } \\
\text { mild hepatitis. }\end{array}$ & $\begin{array}{l}\text { Depression, chronic fatigue } \\
\text { syndrome, }\end{array}$ & $\begin{array}{l}\text { Atypical mononuclear cells } \\
\text { in peripheral film. Positive } \\
\text { Paul-Bunnel reaction } \\
\text { detecting heterophile } \\
\text { antibodies (IgM). }\end{array}$ \\
\hline $\begin{array}{l}\text { Cytomegalovirus } \\
\text { infection }\end{array}$ & $\begin{array}{c}\text { CMV } \\
\text { (one of the } \\
\text { herpes viruses) }\end{array}$ & $\begin{array}{l}\text { Usually asymptomatic (>50\% of } \\
\text { the adult population has } \\
\text { evidence for latent infection). } \\
\text { Symptoms identical to infectious } \\
\text { mononucleosis. Fever, hepatitis } \\
\text { with or without jaundice, } \\
\text { occasionally lymphocytosis } \\
\text { with atypical lymphocytes. }\end{array}$ & $\begin{array}{l}\text { Encephalitis in } \\
\text { immunocompromised } \\
\text { patients, depression, } \\
\text { dementia. }\end{array}$ & $\begin{array}{c}\text { Serological test: Latent (IgG) } \\
\text { or primary (IgM) infection. } \\
\text { Polymerase chain reaction. } \\
\text { Direct immunofluorescence: } \\
\text { characteristic intracellular } \\
\text { “owl-eye” inclusions. } \\
\text { Negative Paul-Bunnell test. }\end{array}$ \\
\hline Measles & $\begin{array}{l}\text { Paramyxo } \\
\text { viruses }\end{array}$ & $\begin{array}{l}\text { Incubation period: } 8 \text { - } 14 \text { days. } \\
\text { Two distinct phases: The } \\
\text { pre-eruptive and catarrhal stage, } \\
\text { the eruptive or exanthematous } \\
\text { stage. }\end{array}$ & $\begin{array}{c}\text { Post infectious } \\
\text { encephalomyelitis, subacute measles } \\
\text { encephalitis, and } \\
\text { subacutesclerosingpanencephalitis } \\
\text { which occurs } 7 \text { - } 10 \text { years following } \\
\text { measles (cognitive dysfunction, } \\
\text { behavior change, headache, } \\
\text { myoclonic jerks). }\end{array}$ & $\begin{array}{l}\text { Most cases diagnosed } \\
\text { clinically }\end{array}$ \\
\hline \multirow{2}{*}{$\begin{array}{l}\text { Flaviviruses } \\
\text { infections } \\
\text { (a group of } 60 \\
\text { viruses) }\end{array}$} & Dengue & $\begin{array}{l}\text { Incubation period is } 5 \text { - } 6 \text { days. } \\
\text { Asymptomatic or mild } \\
\text { infections are common. Can } \\
\text { occur in two clinical forms: } \\
\text { 1.calssic dengue fever, } 2 \text {. } \\
\text { Dengue haemorrhagic fever. }\end{array}$ & $\begin{array}{l}\text { encephalitis, delirium, confusion } \\
\text { and seizures }\end{array}$ & \multirow[t]{2}{*}{$\begin{array}{l}\text { Tissue culture in sera } \\
\text { obtained the first few days } \\
\text { of infection is diagnostic. } \\
\text { ELISA, } \\
\text { Complement-fixing } \\
\text { antibodies. Leucopenia, } \\
\text { thrombocytopenia. }\end{array}$} \\
\hline & $\begin{array}{l}\text { West Nile } \\
\text { Virus }\end{array}$ & $\begin{array}{l}\text { Can be symptomless. Mild } \\
\text { febrile illness. Severe symptoms } \\
\text { may include meningitis and } \\
\text { encephalitis. }\end{array}$ & $\begin{array}{c}\text { Difficulty with memory and } \\
\text { word-finding, fatigue, extremity } \\
\text { weakness, headache, personality } \\
\text { changes, irritability and } \\
\text { aggression. }\end{array}$ & \\
\hline
\end{tabular}




\subsection{Herpes Simplex Virus (HSV) Virus Infection}

Herpes encephalitis is usually caused by HSV-1, while HSV-2 can cause encephalitis mainly in neonates and immunocompromised adults. Herpes encephalitis is the most common cause of sporadic fatal encephalitis (>90\% of cases are caused by HSV-1). Clinical presentation of Herpes encephalitis includes acute fever with various degrees of altered consciousness and behavioral abnormalities such as hallucinations, personality changes, or a frankly psychotic state. It can often present with focal neurological deficits, seizures and myoclonus reflecting the site of infection and inflammation. One of the possible complications of HSV encephalitis is the Kluver-Bucy syndrome (see under section of mycoplasma pneumonia in this article). EEG may show periodic temporal spikes and slow waves (EEG is sensitive but not specific), and MRI may show diffuse inflammation particularly in teproparietal regions [7] [65].

Cognitive impairment including decreased working memory and executive functions has been recognized in schizophrenia which may be partly explained by exposure to certain infectious agents that can lead to central nervous system inflammation (e.g. neurotropic viruses have been associated with focal gray matter deficits in patients with schizophrenia). Serological evidence of infection to HSV1 and cytomegalovirus (CMV) is associated with impaired cognitive functioning among patients with schizophrenia [66]. Seropositivity to HSV-1, related to cognitive deficits and cerebral gray matter changes has been reported in adult schizophrenics [67]. Significant gray matter loss in the posterior cingulate gyrus has been reported among the HSV1-seropositive schizophrenia subjects [68].

The Clinical Antipsychotic Trials of Intervention Effectiveness (CATIE) trial; has shown a significant association between the neurocognitive summary score and antibodies to HSV-1 but not to HSV-2, CMV, or T. gondii. There was a significant association between HSV-1 exposure and the Verbal Memory, Vigilance, and Processing Speed composite scores [69].

The catechol-o-methyl transferase (COMT) Val158Met polymorphism has been associated with cognitive dysfunction in individuals with psychiatric disorders. Serological evidence of HSV-1 was significantly associated with lower total scores for the Repeatable Battery for the Assessment of Neuropsychological Status (RBANS) and the Val/Val genotype of the COMT Val158Met polymorphism. This indicates that infections with HSV-1 and the COMT Val158Val genotype may be one of the risk factors for devolving cognitive deficits [70].

\subsection{Human Immunodeficiency Virus (HIV)}

There is higher Incidence of HIV in patients with schizophrenia (4\% - 23\%) than in the general population [71] [72]. Psychiatric symptoms may occur as a consequence of HIV disease and vice versa. Patients with psychiatric illness have increased risk of contracting HIV infection and that can primarily be due to risky behaviors such as hypersexuality, poor impulse control, self-destructive behavior, casual sexual relationships, lack of risk awareness, impaired judgment, substance abuse, and the potential for sexual victimization [73]. Causes of psychotic symptoms in HIV-seropositive patients include delirium, late-stage HIV-associated dementia, mania, psychoactive substance intoxication, antiretroviral medication toxicities (e.g., efavirenz, particularly in patients with the CYP2B6-G516T polymorphism) and general medical conditions (e.g., cryptococcal meningitis and neurosyphilis) [74]. Generalized anxiety disorder occurs in 15.8\% of HIV-seropositive persons compared with $2.1 \%$ of the general population; while panic disorder occurs in 10.5\% of HIV-seropositive persons versus $2.5 \%$ of the general population [75] [76]. Depressive disorders tend to occur following the first symptoms of HIV infection or in association with a high overall symptom burden [74].

\subsection{Viral Hepatitis}

Acute or chronic hepatitis can be caused by some viruses such as hepatitis A, B, and C viruses, Epstein-Barr virus (EBV) and cytomegalovirus (CMV). Viral hepatitis commonly presents with symptoms of fatigue, malaise and anorexia. Although depression is common in chronic forms of hepatitis B and hepatitis C viral (HCV) infections, but it is important to consider that symptoms of hepatitis can lead to a misdiagnosis of depression [7]. Both HCV infection and its treatment with interferons (IFN) may lead to depressive symptoms. Based on Beck Depression Inventory-Second Edition (BDI-II) scores, a significant proportion of veterans with HCV experienced moderate-to-severe depressive symptoms (34\%). Many of the affected individuals continued to experience depressive symptoms despite receiving antidepressant medications [77]. IFN are naturally-produced cy- 
tokines which have also been synthesized for therapeutic purposes including treatment of a variety of cancers and viral infections. Many psychiatric and behavioral symptoms have been reported under IFN-alpha treatment such as mood disorders which are known to occur early after treatment [78]. The side effects of IFN-alpha include fatigue, myalgia, arthralgia, fever, musculoskeletal pain, irritability and depression. Neuropsychiatric side effects occur in about $50 \%$ of patients treated with IFN, particularly depression. Other neuropsychiatric adverse effects include anxiety, cognitive slowing, impaired concentration and insomnia [79]. Co-occurrence of HCV infection, substance use, and psychiatric illness requires completing IFN treatment with careful monitoring and appropriate intervention [80].

\subsection{Flaviviruses}

Flavivruses group consists of 60 viruses, some of which are transmitted by ticks and others by mosquitoes. Examples of viral infections caused by this group include yellow fever, Japanese encephalitis, West Nile infection and Dengue. The later can be associated with CNS involvement in $3 \%-21 \%$ of cases commonly presenting with encephalitis, delirium, confusion and seizures [81] [82]. West Nile virus is an arthropod-borne flavivirus which spread by infected mosquitoes and can infect birds, human and horses. Most cases are subclinical, with 1 in 5 infected persons developing a mild febrile illness. Severe symptoms may include meningitis and encephalitis. Neuropsychiatric symptoms include difficulty with memory and word-finding, fatigue, extremity weakness, headache, personality changes, irritability and aggression. About 31\% of infected individuals may suffer from depression [18] [83]-[85].

\subsection{Other Viral Infections}

Rabies virus is an RNA virus of the Lyssavirus genus which has two distinct varieties in humans: furious rabies and dumb rabies. The later has symptoms resembling the Gillian-Barre syndrome. The furious/classic variety of rabies can lead to marked psychiatric symptoms 10 days following infection. These symptoms are marked anxiety, agitation and depressive features. Other symptoms include: hallucinations, bizarre behavior, paralysis, hydrophobia, aerophobia and hyperexcitability (the hallmark of furious rabies) [5].

Prion diseases, caused by proteinaceous agents, lead to spongiform changes in the brain. Examples of theses are Kuru (occurring in Papua, New Guinea), and Creutzfeldt-Jakob disease which can lead to psychiatric symptoms several months before developing the neurological symptoms [7].

\section{Pathophysiological Relationship between Infectious Diseases and Neuropsychiatric Symptoms}

Factors that are thought to have role in the pathophysiological relation between infectious diseases and neuropsychiatric symptoms have been recently investigated, particularly that related to toxoplasmosis infection. Depressive symptoms are thought to be dueto IFN- $\gamma$ blocking T. gondii growth through inducing activation of indoleamine-2, 3-dioxygenase and depletion of tryptophan depletion, which results in decreasing serotonin production in the brain [86].

Also, recent data suggest that MicroRNA-132 (miR-132) is up-regulated following Toxoplasma infection and was found to be associated with changes in dopamine receptor signaling [87].

Pathological changes in the brain regions which are induced by chronic toxoplasmosis have been recently investigated in mice and the results have shown that there is impaired local connectivity, particularly within the somatosensory areas. There were was also reduced expression of two cytoskeletal proteins in the somatosensory cortex and hippocampus [88].

Adult patients with HCV infection were found to have increased peripheral immune activation and increased expression of immune-related proteins that are associated with neuropsychiatric symptoms. It has also been reported that altered expression of plasma immune factors may contribute to the severity of neuropsychiatric symptoms [89].

Higher levels of pro-inflammatory cytokines and cortisol have been identified in plasma and cerebrospinal fluid of patients with delirium [90]. The inflammatory marker C-reactive protein (C-RP) has recently been investigated in association with delirium and was thought to be involved in the genesis of delirium [91]. 


\section{Conclusion}

Psychiatric features are common in infectious diseases including bacterial, viral and parasitic infections and they can be the initial presentation, occurring in absence of neurological symptoms, in some cases. Long-term neuropsychiatric complications may also occur. Early identification of the underlying etiology for organic/secondary psychiatric symptoms is essential for appropriate intervention and early treatment of the primary condition that could be the cause of psychiatric symptoms.

\section{References}

[1] Nicolson, G.L. and Haier, J. (2009) Role of Chronic Bacterial and Viral Infections in Neurodegenerative, Neurobehavioral, Psychiatric, Autoimmune and Fatiguing Illnesses: Part 1. BJMP, 2, 20-28.

[2] Marsland, A.L., Bachen, E.A., Cohen, S., Rabin, B. and Manuck, S.B. (2002) Stress, Immune Reactivity and Susceptibility to Infectious Disease. Physiology and Behavior, 77, 711-716. http://dx.doi.org/10.1016/S0031-9384(02)00923-X

[3] DE Hert, M., Correl, C.U. Bobes, J., et al. (2011) Physical Illness in Patients with Severe Mental Disorders. I. Prevalence, Impact of Medications and Disparities in Health Care. World psychiatry, 10, 52-77.

[4] Rothbard, A.B., Blank, M.B., Staab, J.P., Have, T.T., Young, D.S., Berry, S.D. and Eachus, S. (2009) Previously Undetected Metabolic Syndromes and Infectious Diseases among Psychiatric Inpatients. Psychiatric Services, 60, 534537. http://dx.doi.org/10.1176/appi.ps.60.4.534

[5] (2006) Chapter 14. In: Gelder, M., Harrison, P. and Cowen, P., Eds., Shorter Oxford Textbook of Psychiatry, 5th Edition, Oxford University Press, Oxford, 321-357.

[6] (1993) The International classification of Diseases (ICD-10)-Classification of Mental and Behavioral Disorders. WHO, Geneva, 1-267.

[7] Levenson, J.L. (2011) Infectious Diseases. In: Levenson, J.L. Ed., American Psychiatric Association Publishing Textbook of Psychosomatic Medicine, American Psychiatric Publishing, Washington DC, 615-635.

[8] Awadalla, A., Arikawa, H. and Templer, D.I. (1998) The Nature and Structure of Febrile Psychosis in the Sudan. Journal of Orthomolecular Medicine, 13, 136-138.

[9] Markham, J.A. and Koenig, J.I. (2011) Prenatal Stress: Role in Psychotic and Depressive Diseases. Psychopharmacology, 214, 89-106. http://dx.doi.org/10.1007/s00213-010-2035-0

[10] Meyer, U. and Feldon, J. (2009) Neural Basis of Psychosis-Related Behavior in the Infection Model of Schizophrenia. Behavioural Brain Research, 204, 322-334. http://dx.doi.org/10.1016/j.bbr.2008.12.022

[11] Buka, S.L., Tsuang, M.T., Torrey, E.F., Klebanoff, M.A., Bernstein, D. and Yolken, R.H. (2001) Maternal Infections and Subsequent Psychosis among Offspring. Archives of General Psychiatry, 58, 1032-1037. http://dx.doi.org/10.1001/archpsyc.58.11.1032

[12] Brown, A.S., Begg, M.D., Gravenstein, S., et al. (2004) Serologic Evidence of Prenatal Influenza in the Etiology of Schizophrenia. Archives of General Psychiatry, 61, 774-780. http://dx.doi.org/10.1001/archpsyc.61.8.774

[13] Allebeck, P., Gunnell, D. and Harrison, G., et al. (2008) Infections in the CNS during Childhood and the Risk of Subsequent Psychotic Illness: A Cohort Study of More Than One Million Swedish Subjects. American Journal of Psychiatry, 165, 59-65.

[14] Leask, S.J. and Done, D.J. (2002) Adult Psychosis, Common Childhood Infections and Neurological Soft Signs in a National Birth Cohort. The British Journal of Psychiatry, 181, 387-392. http://dx.doi.org/10.1192/bjp.181.5.387

[15] Sørensen, H.J., Mortensen, E.L., Reinisch, J.M. and Mednick, S.A. (2009) Association between Prenatal Exposure to Bacterial Infection and Risk of Schizophrenia. Schizophrenia Bulletin, 35, 631-637. http://dx.doi.org/10.1093/schbul/sbn121

[16] Gilmore, J.H. and Jarskog, L.F. (1997) Exposure to Infection and Brain Development: Cytokines in the Pathogenesis of Schizophrenia. Schizophrenia Research, 24, 365-367. http://dx.doi.org/10.1016/S0920-9964(96)00123-5

[17] Rantakallio, P., Jones, P., Moring, J. and Von Wendt, L. (1997) Association between Central Nervous System Infection during Childhood and Adult Onset Schizophrenia and Other Psychoses: A 28 Year Follow-Up. International Journal of Epidemiology, 26, 837-843. http://dx.doi.org/10.1093/ije/26.4.837

[18] Kumar, P. and Clark, M. (2005) Clinical Medicine. 6th Edition, Chapter 2, Elsevier Saunders, Pheladeliphia, 19-152.

[19] Kitchener, N. (2005) Pediatric Autoimmune Neuropsychiatric Disorders Associated with Streptococcal Infections (PANDAS). International Journal of Child Neuropsychiatry, 2, 195-202.

[20] Levenson, J.L. (2006) Psychiatric Issues in Infectious Diseases. Primary Psychiatry, 13, 29-32.

[21] Swedo, S.E., Leonard, H.L., Garvey, M., Mittleman, B., Allen, A.J., Perlmutter, S., Lougee, L., Dow, S., Zamkoff, J. 
and Dubbert, B.K. (1998) Pediatric Autoimmune Neuropsychiatric Disorders Associated with Streptococcal Infections: Clinical Description of the First 50 Cases. American Journal of Psychiatry, 155, 264-271.

[22] Victor, A.M. and Bernstein, G.A. (2009) Anxiety Disorders and Posttraumatic Stress Disorder Update. Psychiatric Clinics of North America, 32, 57-69. http://dx.doi.org/10.1016/j.psc.2008.11.004

[23] Mell, L.K., Davis, R.L. and Owens, D. (2005) Association between Streptococcal Infection and Obsessive-Compulsive Disorder, Tourette’s Syndrome, and Tic Disorder. Pediatrics, 116, 56-60. http://dx.doi.org/10.1542/peds.2004-2058

[24] Lin, H., Williams, K.A., Katsovich, L., Findley, D.B., Grantz, H., Lombroso, P.J., et al. (2010) Streptococcal Upper Respiratory Tract Infections and Psychosocial Stress Predict Future Tic and Obsessive Compulsive Symptom Severity in Children and Adolescents with Tourette Syndrome and Obsessive-Compulsive Disorder. Biological Psychiatry, 67, 684-691. http://dx.doi.org/10.1016/j.biopsych.2009.08.020

[25] Sinder, L.A., Lougee, L., Slattery, M., Grant, P. and Swedo, S.E. (2005) Antibiotic Prophylaxis with Azithromycin or Penicillin for Childhood-Onset Neuropsychiatric Disorders. Biological Psychiatry, 57, 788-792. http://dx.doi.org/10.1016/j.biopsych.2004.12.035

[26] Moor, S. and Skrine, H. (1989) Psychosis in Mycoplasma Infection. Postgraduate Medical Journal, 65, 96-97. http://dx.doi.org/10.1136/pgmj.65.760.96

[27] Narita, M. (2009) Pathogenesis of Neurologic Manifestations of Mycoplasma pneumoniae Infection. Pediatric Neurology, 41, 159-166. http://dx.doi.org/10.1016/j.pediatrneurol.2009.04.012

[28] Koskiniemi, M. (1993) CNS Manifestations Associated with Mycoplasma pneumoniae Infections: Summary of Cases at the University of Helsinki and Review. Clinical Infectious Diseases, 17, S52-S57. http://dx.doi.org/10.1093/clinids/17.Supplement_1.S52

[29] Banerjee, B. and Petersen, K. (2009) Psychosis Following Mycoplasma pneumonia. Military Medicine, 174, $1001-1004$. http://dx.doi.org/10.7205/MILMED-D-00-8209

[30] Candler, P.M. and Dale, R.L. (2004) Three Cases of Central Nervous System Complications Associated with Mycoplasma pneumoniae. Pediatric Neurology, 31, 133-138. http://dx.doi.org/10.1016/j.pediatrneurol.2004.02.011

[31] Auvichayapat, N., Auvichayapat, P., Watanatorn, J., Thamaroj, J. and Jitpimolmard, S. (2006) Kluver-Bucy Syndrome after Mycoplasmal Bronchitis. Epilepsy \& Behavior, 8, 320-322. http://dx.doi.org/10.1016/j.yebeh.2005.10.005

[32] Daxbeck, F. (2006) Mycoplasma pneumoniae Central Nervous System Infections. Current Opinion in Neurology, 19, 374-378. http://dx.doi.org/10.1097/01.wco.0000236617.04958.60

[33] Chou, C.L., Lin, Y.J., Sheu, Y.L., Lin, C.J. and Hseuh, H. (2008) Persistent Klüver-Bucy Syndrome after Bilateral Temporal Lobe Infarction. Acta Neurologica Taiwanica, 17, 199-202.

[34] Hildenbrand, P., Craven, D.E., Jones, R. and Nemeskal, P. (2009) Lyme Neuroborreliosis: Manifestations of a Rapidly Emerging Zoonosis. AJNR American Journal of Neuroradiology, 30, 1079-1087. http://dx.doi.org/10.3174/ajnr.A1579

[35] Fallon, B.A. and Nields, J.A. (1994) Lyme Disease: A Neuropsychiatric Illness. American Journal of Psychiatry, 151, 1571-1583.

[36] Hurley, R.A. and Taber, K.H. (2008) Acute and Chronic Lyme Disease: Controversies for Neuropsychiatry. Journal of Neuropsychiatry, 20, 4-6. http://dx.doi.org/10.1176/appi.neuropsych.20.1.iv

[37] Nicolson, G.L. and Haier, J. (2010) Role of Chronic Bacterial and Viral Infections in Neurodegenerative, Neurobehavioral, Psychiatric, Autoimmune and Fatiguing Illnesses: Part 2. British Journal of Medical Practitioners, 3, 301.

[38] Straight, T.M. and Martin, G.J. (2002) Current Treatment Options in Infectious Diseases. Current Science Inc., 4, 447-456.

[39] Tuncel, D., Uçmak, H., Gokce, M. and Utku, U. (2008) Neurobrucellosis. European Journal of General Medicine, 5, 245-248.

[40] Karsen, H., Akdeniz, H., Karahocagil, M.K., Irmak, H. and Sünnetçioğlu, M. (2007) Toxic-Febrile Neurobrucellosis, Clinical Findings and Outcome of Treatment of Four Cases Based on Our Experience. Scandinavian Journal of Infectious Diseases, 39, 990-995. http://dx.doi.org/10.1080/00365540701466199

[41] Shehata, G.A., Abdel-Baky, L., Rashed, H. and Elamin, H. (2010) Neuropsychiatric Evaluation of Patients with Brucellosis. Journal of NeuroVirology, 16, 48-55. http://dx.doi.org/10.3109/13550280903586386

[42] Reitan, R.M. (1953) Intellectual and Affective Functions in Chronic Brucellosis. American Journal of Psychiatry, 110, 19-28.

[43] Webster, J.P., Lamberton, P.H.L., Donnelly, C.A. and Torrey, E.F. (2006) Parasites as Causative Agents of Human Affective Disorders? The Impact of Anti-Psychotic, Mood-Stabilizer and Anti-Parasite Medication on Toxoplasma gondii’s Ability to Alter Host Behavior. Proceedings of the Royal Society B: Biological Sciences, 273, 1023-1030. http://dx.doi.org/10.1098/rspb.2005.3413 
[44] Alvarado-Esquivel, C., Alanis-Quiñones, O.P., Arreola-Valenzuela, M.Á., Rodríguez-Briones, A., Piedra-Nevarez, L.J., Duran-Morales, E., Estrada-Martínez, S., Martínez-García, S.A. and Liesenfeld, O. (2006) Seroepidemiology of Toxoplasma gondii Infection in Psychiatric Inpatients in a Northern Mexican City. BMC Infectious Diseases, 6, 178. http://dx.doi.org/10.1186/1471-2334-6-178

[45] Torrey, E.F. and Yolken, R.H. (2003) Toxoplasma gondii and Schizophrenia. Emerging Infectious Diseases, 9, 13751380. http://dx.doi.org/10.3201/eid0911.030143

[46] Arendt, G., Von Giesen, H.J., Hefter, H., Neuen-Jacob, E., Roick, H. and Jablonowski, H. (1999) Long-Term Course and Outcome in AIDs Patients with Cerebral Toxoplasmosis. Acta Neurologica Scandinavica, 100, 178-184. http://dx.doi.org/10.1111/j.1600-0404.1999.tb00735.x

[47] Henriquez, S.A., Brett, R., Alexander, J., Pratt, J. and Roberts, C.W. (2009) Neuropsychiatric Disease and Toxoplasma gondii Infection. NeuroImmunomodulation, 16, 122-133. http://dx.doi.org/10.1159/000180267

[48] Alvarado-Esquivel, C., Urbina-Álvarez, J.D., Estrada-Martínez, S., Torres-Castorena, A., Molotla-de-León, G., Liesenfeld, O. and Dubey, J.P. (2011) Toxoplasma gondii Infection and Schizophrenia: A Case Control Study in a Low Toxoplasma Seroprevalence Mexican Population. Parasitology International, 60, 151-155. http://dx.doi.org/10.1016/j.parint.2010.12.003

[49] Tedla, Y., Shibre, T., Ali, O., Tadele, G., Woldeamanuel, Y., Asrat, D., Aseffa, A., Mihret, W., Abebe, M., Alem, A., Medhin, G. and Habte, A. (2011) Serum Antibodies to Toxoplasma gondii and Herpesvidae Family Viruses in Individuals with Schizophrenia and Bipolar Disorder: A Case-Control Study. Ethiopian Medical Journal, 49, 211-220.

[50] Webster, J.P., Lamberton, P.H.L., Donnelly, C.A. and Torrey, E.F. (2006) Parasites as Causative Agents of Human Affective Disorders? The Impact of Anti-Psychotic, Mood-Stabilizer and Anti-Parasite Medication on Toxoplasma gondii’s Ability to Alter Host Behavior. Proceedings of the Royal Society B: Biological Sciences, 273, 1023-1030. http://dx.doi.org/10.1098/rspb.2005.3413

[51] Webster, J.P. (2007) The Effect of Toxoplasma gondii on Animal Behavior: Playing Cat and Mouse. Schizophrenia Bulletin, 33, 752-756. http://dx.doi.org/10.1093/schbul/sbl073

[52] Adamec, R.E., Burton, P., Shallow, T. and Budgell, J. (1999) NMDA Receptors Mediate Lasting Increases in Anxiety-Like Behavior Produced by the Stress of Predator Exposure-Implications for Anxiety Associated with Posttraumatic Stress Disorder. Physiology \& Behavior, 65, 723-737. http://dx.doi.org/10.1016/S0031-9384(98)00226-1

[53] Blanchard, R.J., Blanchard, D.C., Rodgers, J. and Weiss, S.M. (1990) The Characterization and Modelling of Antipredator Defensive Behavior. Neuroscience \& Biobehavioral Reviews, 14, 463-472. http://dx.doi.org/10.1016/S0149-7634(05)80069-7

[54] Castelli, F., Odolini, S., Autino, B., Foca, E. and Russo, R. (2010) Malaria Prophylaxis: A Comprehensive Review. Pharmaceuticals, 3, 3212-3239. http://dx.doi.org/10.3390/ph3103212

[55] Dondorp, A.M. (2005) Pathophysiology, Clinical Presentation and Treatment of Cerebral Malaria. Neurology Asia, 10, 67-77.

[56] Kumar, D., Patel, N., Pradeep, P., Surti, M.M. and Agarwal, S.B. (2003) Clinical Manifestations of Complicated Malaria-An Overview. JIACM, 4, 323-331.

[57] Idro, R., March, K., John, C.C. and Newton, C.R.J. (2010) Cerebral Malaria: Mechanism of Brain Injury and Strategies for Improved Neurocognitive Outcome. Pediatric Research, 68, 267-274. http://dx.doi.org/10.1203/PDR.0b013e3181eee738

[58] Telgt, D.S. (2005) Serious Psychiatric Symptoms after Chloroquine Treatment Following Experimental Malaria Infection. The Annals of Pharmacotherapy, 39, 551-554. http://dx.doi.org/10.1345/aph.1E409

[59] Wooltorton, E. (2002) Mefloquine: Contraindicated in Patients with Mood, Psychotic or Seizure Disorders. Canadian Medical Association Journal, 176, 1147.

[60] Ronn, A.M., Ronne-Rasmussen, J., Gotzsce, P.C. and Bygbjerg, I.C. (1998) Neuropsychiatric Manifestations after Mefloquine Therapy for Plasmodium falciparum Malaria: Comparing a Retrospective and a Prospective Study. Tropical Medicine and International Health, 3, 83-88. http://dx.doi.org/10.1046/j.1365-3156.1998.00163.x

[61] Tran, T.M., Browning, J. and Dell, M.L. (2006) Psychosis with Paranoid Delusions after Atherapeutic Dose of Mefloquine: A Case Report. Malaria Journal, 5, 74. http://dx.doi.org/10.1186/1475-2875-5-74

[62] Garg, P., Mody, P. and Lall, K.B. (1990) Toxic Psychosis Due to Chloroquine-Not Uncommon in Children. Clinical Pediatrics, 29, 448-450. http://dx.doi.org/10.1177/000992289002900806

[63] Chadwick, D.R. (2005) Viral Meningitis. British Medical Bulletin, 75-76, 1-14.

[64] Caroff, S.N., Mann, S.C., Glittoo, M.F., Sullivan, K.A. and Campbell, E.C. (2001) Psychiatric Manifestations of Acute Viral Encephalitis. Psychiatric Annals, 32, 193-204. http://dx.doi.org/10.3928/0048-5713-20010301-10

[65] Lakeman, F.D. and Whitley, R.J. (1995) Diagnosis of Herpes Simplex Encephalitis: Application of Polymerase Chain 
Reaction to Cerebrospinal Fluid from Brain-Biopsied Patients and Correlation with Disease. Journal of Infectious Diseases, 171, 857-863. http://dx.doi.org/10.1093/infdis/171.4.857

[66] Shirts, B.H., Prasad, K.M., Pogue-Geile, M.F., Dickerson, F., Yolken, R.H. and Nimgaonkar, V.L. (2008) Antibodies to Cytomegalovirus and Herpes Simplex Virus 1 Associated with Cognitive Function in Schizophrenia. Schizophrenia Research, 106, 268-274. http://dx.doi.org/10.1016/j.schres.2008.07.017

[67] Niebuhr, D.W., Millikan, A.M., Yolken, R., Li, Y. and Weber, N.S. (2007) Results from a Hypothesis Generating Case-Control Study: Herpes Family Viruses and Schizophrenia among Military Personnel. Schizophrenia Bulletin, 34, 1182-1188.

[68] Prasad, K.M., Eack, S.M., Goradia, D., Pancholi, K.M., Keshavan, M.S., Yolken, R.H. and Nimgaonkar, V.L. (2011) Progressive Gray Matter Loss and Changes in Cognitive Functioning Associated with Exposure to Herpes Simplex Virus 1 in Schizophrenia: A Longitudinal Study. American Journal of Psychiatry, 168, 822-830. http://dx.doi.org/10.1176/appi.ajp.2011.10101423

[69] Yolken, R.H., Torrey, E.F., Lieberman, J.A., Yang, S. and Dickerson, F.B. (2011) Serological Evidence of Exposure to Herpes Simplex Virus Type 1 Is Associated with Cognitive Deficits in the CATIE Schizophrenia Sample. Schizophrenia Research, 128, 61-65. http://dx.doi.org/10.1016/j.schres.2011.01.020

[70] Dickerson, F., Stallings, C., Sullens, A., Origoni, A., Leister, F., Krivogorsky, B. and Yolken, R. (2008) Association between Cognitive Functioning, Exposure to Herpes Simplex Virus Type 1, and the COMT Val158Met Genetic Polymorphism in Adults without a Psychiatric Disorder. Brain, Behavior, and Immunity, 22, 1103-1107. http://dx.doi.org/10.1016/j.bbi.2008.04.156

[71] Davidson, S., Judd, F., Jolley, D., Hocking, B., Thompson, S. and Hyland, B. (2001) Risk Factors for HIV/AIDS and Hepatitis C among the Chronic Mentally Ill. Australian \& New Zealand Journal of Psychiatry, 35, 203-209. http://dx.doi.org/10.1046/j.1440-1614.2001.00867.x

[72] Cournos, F. and McKinnon, K. (1997) HIV Seroprevalence among People with Severe Mental Illness in the United States: A Critical Review. Clinical Psychology Review, 17, 259-269. http://dx.doi.org/10.1016/S0272-7358(97)00018-4

[73] Dolder, C.R., Patterson, T.L. and Jeste, D.V. (2004) HIV, Psychosis and Aging: Past, Present and Future. AIDS, 18, 35-43.

[74] Goodkin, K. (2009) Psychiatric Aspects of HIV Spectrum Disease. FOCUS, 7, 303-310.

[75] Bing, E.G., Burnam, M.A., Longshore, D., Fleishman, J.A., Sherbourne, C.D., London, A.S., Turner, B.J., Eggan, F., Beckman, R., Vitiello, B., Morton, S.C., Orlando, M., Bozzette, S.A., Ortiz-Barron, L. and Shapiro, M. (2001) Psychiatric Disorders and Drug Use among Human Immunodeficiency Virus-Infected Adults in the United States. Archives of General Psychiatry, 58, 721-728.

[76] Tsao, J.C.I., Dobalian, A. and Naliboff, B.D. (2004) Panic Disorder and Pain in a National Sample of Persons Living with HIV. Pain, 109, 172-180. http://dx.doi.org/10.1016/j.pain.2004.02.001

[77] Nelligan, J.A., Loftis, J.M., Matthews, A.M., Zucker, B.L., Linke, A.M. and Hauser, P. (2008) Depression Comorbidity and Antidepressant Use in Veterans with Chronic Hepatitis C: Results from a Retrospective Chart Review. Journal of Clinical Psychiatry, 69, 810-816. http://dx.doi.org/10.4088/JCP.v69n0514

[78] Vignau, J., Karila, L., Costisella, O. and Canva, V. (2005) Hepatitis C, Interferon $\alpha$ and Depression: Main Physiopathologic Hypothesis. L’Encéphale, 31, 349-357. http://dx.doi.org/10.1016/S0013-7006(05)82400-5

[79] Fireman, M., Indest, D.W., Blackwell, A., Whitehead, A.J. and Hauser, P. (2005) Adressing Tri-Morbidity (Hepatitis C, Psychiatric Disorders and Substance Use): The Importance of Routine Mental Health Screening as a Component of a Comanagement Model of Care. Clinical Infectious Diseases, 40, S286-S291. http://dx.doi.org/10.1086/427442

[80] Sylvestre, D.L., Loftis, J.M., Hauser, P., Genser, S., Cesari, H., Borek, N., Kresina, T.F., Seeff, L. and Francis, H. (2004) Co-Occurring Hepatitis C, Substance Use, and Psychiatric Illness: Treatment Issues and Developing Integrated Models of Care. Journal of Urban Health, 81, 719-34. http://dx.doi.org/10.1093/jurban/jth153

[81] Wasay, M., Channa, R., Jumani, M., Shabbir, G., Azeemuddin, M. and Zafar, A. (2008) Encephalitis and Myelitis Associated with Dengue Viral Infection: Clinical and Neuroimaging Features. Clinical Neurology and Neurosurgery, 110, 635-640. http://dx.doi.org/10.1016/j.clineuro.2008.03.011

[82] Domingues, R.B., Kuster, G.W., Onuki-Castro, F.L., Souza, V.A., Levi, J.E. and Pannuti, C.S. (2008) Involvement of the Central Nervous System in Patients with Dengue Virus Infection. Journal of the Neurological Sciences, 267, 36-40. http://dx.doi.org/10.1016/j.jns.2007.09.040

[83] Hunsperger, E.A. and Roehrig, J.T. (2006) Temporal Analyses of the Neuropathogenesis of a West Nile Virus Infection in Mice. Journal of NeuroVirology, 12, 129-139. http://dx.doi.org/10.1080/13550280600758341

[84] Murray, K.O., Resnick, M. and Miller, V. (2007) Depression after Infection with West Nile Virus. Emerging Infectious Diseases, 13, 479-481. http://dx.doi.org/10.3201/eid1303.060602 
[85] Watson, N.K., Bartt, R.E., Houff, S.A., Leurgans, S.E. and Schneck, M.J. (2005) Focal Neurological Deficits and West Nile Virus Infection. Clinical Infectious Diseases, 40, e59-e62. http://dx.doi.org/10.1086/428117

[86] Hsu, P.C., Groer, M. and Beckie, T. (2014) New Findings: Depression, Suicide, and Toxoplasma gondii Infection. Journal of the American Association of Nurse Practitioners, Epub Ahead of Print.

[87] Xiao, J., Li, Y., Prandovszky, E., Karuppagounder, S.S., Talbot Jr., C.C., Dawson, V.L., Dawson, T.M. and Yolken, R.H. (2014) MicroRNA-132 Dysregulation in Toxoplasma gondii Infection Has Implications for Dopamine Signaling Pathway. Neuroscience, 268, 128-138. http://dx.doi.org/10.1016/j.neuroscience.2014.03.015

[88] Parlog, A., Harsan, L.A., Zagrebelsky, M., Weller, M., von Elverfeldt, D., Mawrin, C., Korte, M. and Dunay, I.R. (2014) Chronic Murine Toxoplasmosis Is Defined by Subtle Changes in Neuronal Connectivity. Disease Models \& Mechanisms, 7, 459-469.

[89] Huckans, M., Fuller, B.E., Olavarria, H., Sasaki, A.W., Chang, M., Flora, K.D., Kolessar, M., Kriz, D., Anderson, J.R., Vandenbark, A.A. and Loftis, J.M. (2014) Multi-Analyte Profile Analysis of Plasma Immune Proteins: Altered Expression of Peripheral Immune Factors Is Associated with Neuropsychiatric Symptom Severity in Adults with and without Chronic Hepatitis C Virus Infection. Brain and Behavior, 4, 123-142. http://dx.doi.org/10.1002/brb3.200

[90] Cerejeira, J., Lagarto, L. and Mukaetova-Ladinska, E.B. (2014) The Immunology of Delirium. Neuroimmunomodulation, 21, 72-78.

[91] Ritchie, C.W., Newman, T.H., Leurent, B. and Sampson, E.L. (2014) The Association between C-Reactive Protein and Delirium in 710 Acute Elderly Hospital Admissions. International Psychogeriatrics, 26, 717-724.

http://dx.doi.org/10.1017/S1041610213002433 
Scientific Research Publishing (SCIRP) is one of the largest Open Access journal publishers. It is currently publishing more than 200 open access, online, peer-reviewed journals covering a wide range of academic disciplines. SCIRP serves the worldwide academic communities and contributes to the progress and application of science with its publication.

Other selected journals from SCIRP are listed as below. Submit your manuscript to us via either submit@scirp.org or Online Submission Portal.
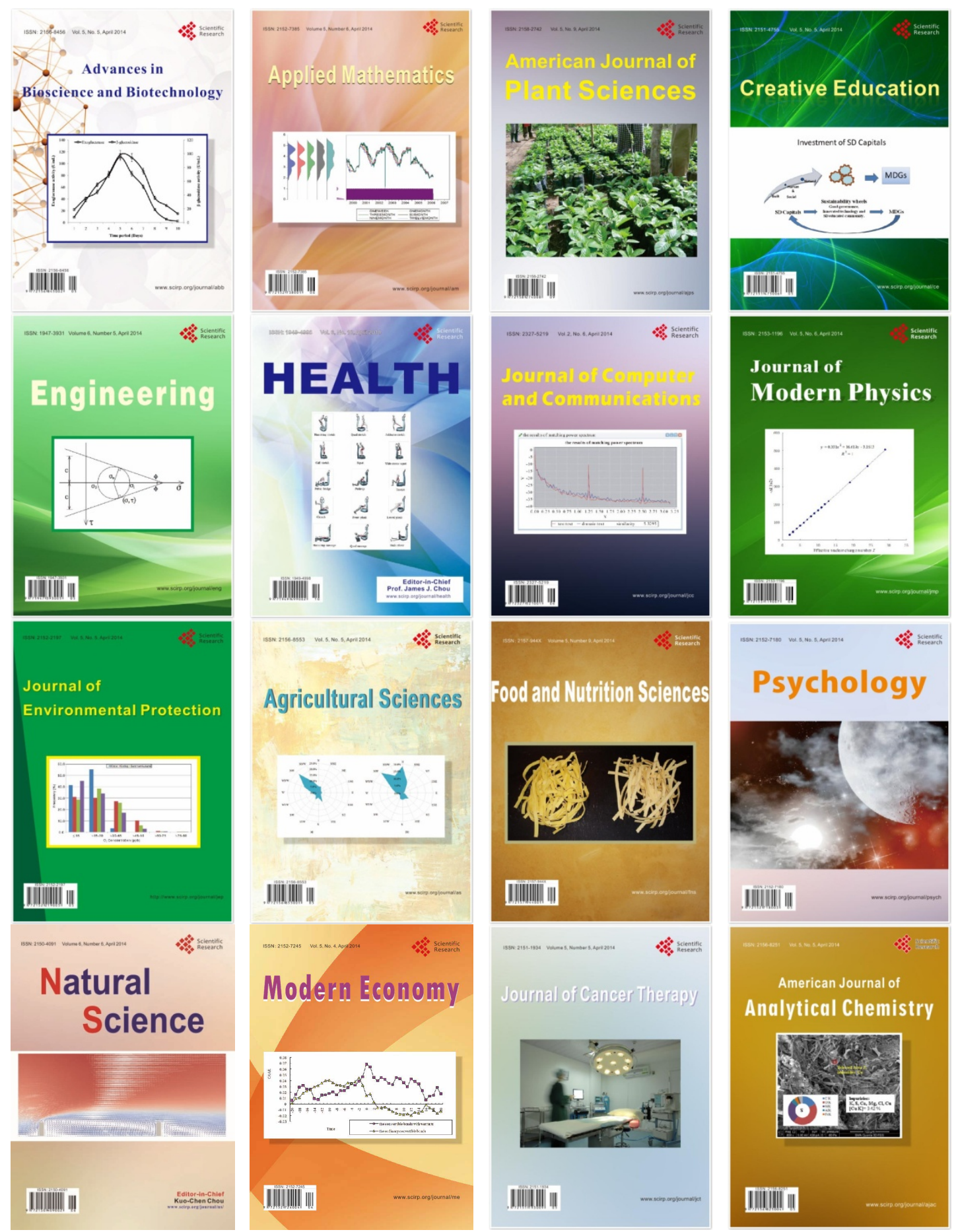